The analysis showed that additional attention in maritime higher education institutions is directed to the issues of port mechanization, water transport and shelf structures, transport technologies and systems, engineering hydrobiology, navigation, engineering, maritime transport and technology, ship navigation and energy, marine ecology, safety, river transport, maritime logistics. It was found that universities consider working with foreign students to be one of their priorities.

The analysis of modern areas of training in higher education institutions of the maritime profile shows three main trends: the preservation of classical maritime specialties in spite of financial difficulties due to the low level of group size; updating the areas of training in accordance with the requirements of the time and the requests of applicants, when the specialties "Management", "Economics", "Maritime Law", etc. are introduced, but the vector of application of acquired knowledge in the maritime field is preserved; organization of international cooperation (from the declarative level of cooperation with foreign higher education institutions to the education of foreign students).

Key words: maritime higher education institutions, history of maritime education, shipbuilding, directions of training of specialists in maritime higher education institutions, students, Admiral Makarov National University of Shipbuilding.

Дата надходження статті: 11.01.2021 p. Рецензент: доктор педагогічних наук, доцент Рябуха I. М.

UDC 378:656.2-051(477.7)(09)«19/20»(043.3)

DOI https://doi.org/10.37915/pa.vi48.229

Kovalenko O. M. , orcid.org/0000-0001-7900-6226

\title{
THE IMPLEMENTATION OF THE EXPERIENCE OF FUTURE RAILWAY EXPERTS TRAINING INTO THE MODERN EDUCATION PROCESS
}

The article deals with the implementation of the experience of future railway experts training into the modern education process. The author underlines that the problem of the railway experts training is relevant during the whole period of the existence of the railway educational institutions. The burning questions are as follows: the continuity of the academic syllabi and curriculums at the different levels of the education, the correspondence of the training level to the labour conditions and railroad requirements, the dual education system, etc. In the past (the second half of the XX) the process of railway experts training was stipulated by several factors. One of them was the scientific and technical development of railway transport (for instance, the replacement of steam trains and diesel locomotives with electrical locomotives; the application of automatic systems in the railway operation, etc.). Another factor is railroad enterprise requirements (as the railway transport develops the enterprises need more qualified workers or employees with some new qualification). Thus, the railway industry required new skilled workers and the institution of railway education aimed at the training of skilled workers for different railroad branches. To achieve the aim vocational schools launched new majors and created new academic syllabi and curriculum which were relevant for the railway requirements. The author summarizes that taking into account the previous historical background, it would make sense to arrange future railway experts training at enterprises with the participation of the employees who work at the enterprise. Training within the industry has to take more than half of the total teaching hours. Such an approach provides balanced acquirement by hard and soft skills: professional knowledge and abilities, necessary key competencies as well as communicative skills, teamwork, critical thinking, etc. The author offers the draft syllabus which can be used for railway experts training within the dual education system programme.

Keywords: implementation, dual education, syllabus, curriculum, railway workers, railway experts training.

*C Kovalenko O.M.

بs 240 
The statement of the issue. Modern society is getting more globalized. Globalization covers all spheres of life including education. The Bologna Process and the transfer system allow students to obtain education and being highly employable in different countries. That is why the issue of the flexibility and recognition of academic curriculums. To improve these curriculums it is necessary to be ruled not only by the state regulations and requirements but to use world experience [5, p. 38].

The problem of the railway experts training is relevant during the whole period of the existence of the railway educational institutions. The burning questions are as follows: the continuity of the academic syllabi and curriculums at the different levels of the education, the correspondence of the training level to the labour conditions and railroad requirements, the dual education system, etc. [2; 4].

The analysis of relevant research. A lot of Ukrainian and foreign researchers investigated the problem of railway experts training: V. Bahlay, O. Bessarabova, O. Hruzdieva, I. Karapetiants, N. Labareshnykh, T. Marushchak, I. Skliarenko, E. Tumazu, Ya. Kharder, O. Khomuliak, T. Sharhun, E. Shefiieva, etc. The issues investigated by these scientists cover a wide range of problems such as railway experts training under globalisation conditions, reforming and modernisation of the Ukrainian education system, the comparative analysis of railway workers training in Ukraine and abroad, etc.

In recent decades the dual education system has been researched by various scientists using different approaches and trends. Thus, the dual education system as an adult education model was researched by M. Dernova (2014), the dual education system for skilled staff training as a way to reform higher educational institutions is investigated by R. Oleksenko (2017). O. Korkun, I. Korkun and O. Tsilnyk (2018) analyse the dual education system as a guarantee for workforce capacity. O. Boltianskyi and N. Boltianska (2020) cover the problem of the dual education system as a way to professional mobility of graduates in higher educational institutions.

However, the dual education system in the railway industry has still been understudied. The papers which cover the mentioned above problem include an article by L. Polishchuk (2018) who investigate the implementation of the dual education system for railway staff training; the work by V. Bakatanova and V. Bahlay (2018) who highlight an expert evaluation of the dual education system in a work training centre; a collective work by S. Panchenko, S. Prikhodko, O. Kameniev, A. Lapko, L. Vasyleha, Yu. Tereshchenko (2020) researches the prospective growth of the dual education system for railway highly trained professionals training, a research made by V. Hatchenko (2020) .who deals with the railway experts competencies while implementing the dual education system.

The purpose of the article is to research the implementation of the experience of the future railway experts training into the modern educational process.

The body of the research. The process of railway experts training in the second half of the $\mathrm{XX}$ was stipulated by several factors. One of them was the scientific and technical development of railway transport (for instance, the replacement of steam trains and diesel locomotives with electrical locomotives; the application of automatic systems in railway operation, etc.). Another factor is railroad enterprise requirements (as the railway transport develops the enterprises need more qualified workers or employees with some new qualification) [3, p. 138].

Thus, the railway industry required new skilled workers and the institution of railway education aimed at the training of skilled workers for different railroad branches. To achieve the aim vocational schools launched new majors and created new academic syllabi and curriculum which were relevant for the railway requirements. Except the training at the vocational schools, future railway experts were able to obtain some vocational education at the enterprises. Such training was regulated by special requirements for academic syllabi and curriculum for training and upgrading qualifications of the staff at the enterprises. The curriculums designed based on the requirements covered all the

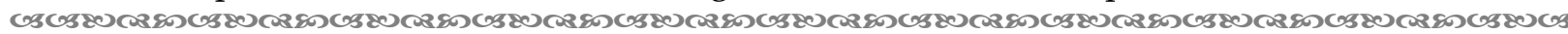


necessary courses which were necessary to prepare a future railway worker for the work at the railway enterprise. The integral part of this training program was a big amount of hours which were given for training within industry course. This course took more than half of the total numbers of hours that made it highly efficient for obtaining practical skills which are necessary in the railway industry [6].

As V. Hatchenko mentioned in his article the dual education is possible as on Bachelor as on Master level. He underlines that hours given to the theoretical and practical courses can be varied and training within industry hours can be increased if approved by an employer. According to V. Hatchenko's structural plan for railway experts training on Bachelor level while obtaining the dual education, are divided into 4 years and calculated in the per cent $[1$, p. 48$]$.

In the first and second academic years, the theoretical course consists of basic courses $(50 \%)$, at the third academic year it includes special courses $(30 \%)$, at the fourth academic year students have innovations and management courses $(20 \%)$. The practical course takes $40 \%$ at the first and second years of study, the same amount at the third year of study and $20 \%$ at the fourth year of study. Basic courses learnt during the first and the second academic years are divided into technical basic courses and humanities. Basic technical courses include higher mathematics, physics, chemistry, drawing, strength of materials, electrical engineering, material engineering, mechanism and machine theory, etc. Humanities are the following: philosophy, a foreign language, cultural studies, ethics, etc. Special courses are designed according to the enterprise's requirements and include maintenance fundamentals, repair technology, diagnostic engineering, the theory and structure of a mechanism, major components functioning, basis of design and development of technical data package. Innovations and management courses cover new methods of improvement in the railway industry and classes which are connected with the manager's organization and planning: economics, industrial engineering, ecological engineering, management, labour safety, business English [1, p. 49].

To obtain practical skills first- and second-year students are to learn about the enterprise, labour conditions, enterprise statute, fitting skills, some basic information about techniques, equipment and mechanisms, workplace hygiene. For the third-year students, it is necessary to learn some information about the enterprise's departments and branches, operation and maintenance facilities, equipment and mechanism repair, hi-tech equipment operation, robotic marking, computer-based workbenches, technical documents, etc. graduates obtain knowledge of field-specific practical skills of a specific type of operational procedures, management skills for railway department/branch operation [1, p. 50].

To our mind, taking into account the previous historical background, it would make sense to arrange future railway experts training at enterprises with the participation of the employees who work at the enterprise. Training within the industry has to take more than half of the total teaching hours. Such an approach provides balanced acquirement by hard and soft skills: professional knowledge and abilities, necessary key competencies as well as communicative skills, teamwork, critical thinking, etc.

Summarizing the results of our investigation we would like to offer a sketch academic syllabus for railway experts training using the dual education system (Table 1).

As you can see from Table 1 we recommend spending more credits for training within the industry ( 40 credits). The least number of credits are for the basic technical course ( 5 credits). All credits are divided between weeks 1-20. Weeks 21-22 are devoted to consultations and exams. Training within the industry could not only include some practical lessons but some theoretical background as well. But the implementation of such a syllabus has several challenges which are as follows: scheduling of academic hours between an educational institution and the enterprise, establishing of special academic departments at the enterprise which are responsible for teaching, labour expenses for those railway employees at the enterprise who are engaged in training of students, the shortage of academic

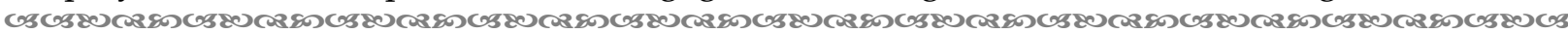
242 



ПЕДАГОГІЧНИЙ АЛЬМАНАХ. - 2021. - ВИПУСК 48

U3

workload in educational establishments, etc. all of the above have to be discussed with stakeholders, community and be regulated by the government.

Table 1

A sketch academic syllabus for railway experts training for one academic year

\begin{tabular}{|c|c|c|c|c|c|}
\hline \multirow[t]{3}{*}{ No } & \multirow[t]{3}{*}{ Content (courses, subjects) } & \multicolumn{3}{|c|}{ Weeks } & \multirow{3}{*}{$\begin{array}{c}\text { Total } \\
\text { credits }\end{array}$} \\
\hline & & $1-15$ & $16-20$ & 21-22 & \\
\hline & & \multicolumn{3}{|c|}{ Hours per week } & \\
\hline I & Training within industry & 25 & 15 & - & 40 \\
\hline II & Theoretical course & & & & \\
\hline 1 & $\begin{array}{l}\text { Special course (maintenance } \\
\text { fundamentals, repair } \\
\text { technology, diagnostic } \\
\text { engineering, the theory and } \\
\text { structure of a mechanism, major } \\
\text { components functioning, basis of } \\
\text { design and development of } \\
\text { technical data package, etc.) }\end{array}$ & 8 & 6 & - & 14 \\
\hline 2 & $\begin{array}{l}\text { Basic technical course } \\
\text { (mathematics, physics, } \\
\text { chemistry, drawing, the strength } \\
\text { of materials, electrical } \\
\text { engineering, material } \\
\text { engineering, mechanism and } \\
\text { machine theory, etc.) }\end{array}$ & 5 & - & - & 5 \\
\hline & Consultations & - & - & 0.5 & 0.5 \\
\hline & Exams & - & - & 0.5 & 0.5 \\
\hline & Total & 38 & 21 & 1 & 60 \\
\hline
\end{tabular}

${ }^{*}$ Designed by the author.

The training within the industry allows not only training but obtaining a specific profession. Within the period of study future railway experts will be able to receive a profession in addition to their own.

Conclusions. Thus, taking into account previous experience and the current situation it could be said that railway experts' training is a burning problem which needs regulation at the government level. It should be mutual efforts of the Ministry of Education and Science of Ukraine, the Ministry of Infrastructure, educational institutions and enterprises. The dual education system is only one of the ways which can help to improve future railway experts training. It is one of the most efficient systems which is used successfully all over the world and its implementation into the current educational process can lead to the highly positive results in railway experts training. These results can support and develop the railway industry, to provide new highly-qualified employees, to make railway workers competitive in the labour market.

Perspectives of our following research will be aimed at studying the use of some innovative methods and techniques for future railway experts training.

\section{Bibliography:}

1. Гатченко В.О. Процес формування компетентностей фахівців залізничної галузї під час впровадження дуальної форми навчання/, Дуальна форма здобуття освіти: успіхи та проблеми периого року запровадження пілотного проекту у закладах фахової передвищої освіти України: матеріали Міжнародної науково-практичної конференції (м. Київ, 22 жовтня 2020 року). Київ: Науково-методичний центр ВФПО, 2020. С. 48-50.

2. Дуальна освіта у залізничній галузі. URL: https://www.railinsider.com.ua/v-uz-rozpovily-yakvprovadzhuyetsya-dual 
3. Коваленко О. М. Підготовка майбутніх фахівців залізничного транспорту на підприємствах України (80-ті - початок 90-х рр. XX ст.). Теоретико-методологічні основи розвитку освіти тауправління навчальними закладами: матеріали VI Всеукраїнської (з іноземною участю) науково-практичної конференції (м. Херсон, 20 листопада 2020 року). Херсон: КВНЗ «Херсонська академія неперервної освіти», 2020. Ч. І. С. 137-141.

4. Концепція дуальної освіти в https://www.google.com/url?sa=t\&rct=j\&q=\&esrc=s\&source=web\&cd=\&ved=2ahUKEwjHqcTsivH wAhXkhf0HHcwJC0EQFjABegQIBBAD\&url=https\%3A\%2F\%2Fmon.gov.ua\%2Fstorage\%2Fapp\% 2Fmedia\%2Fkolegiya-ministerstva\%2F02\%2Fkontseptsii-dualnoiosviti.doc\&usg=AOvVaw2NRBaEU9808aQDn9VXCJi2

5. Слюсаренко Н. В., Коваленко А. М. Подготовка специалистов железнодорожного транспорта: международный опыт. Доклады Казахской академии образования / редкол. А. К. Кусайынов (глава) и др. Астана, 2018. № 5. С. 38-46.

6. Требования к разработке учебных планов и программ для подготовки и повышения квалификации рабочих на производстве: от 19 января 1983 года. URL: http://docs.cntd.ru/document/420273676

\section{References:}

1. Hatchenko, V. O. (2020). Protses formuvannia kompetentnostei fakhivtsiv zaliznychnoi haluzi pid chas vprovadzhennia dualnoii formy navchannia [The process of the formation of railway experts competencies during the dual education system implementation]. Kyiv: Naukovo-metodychnyi tsentr VFPO [in Ukrainian].

2. Dualna osvita $u$ zaliznychnii haluzi [The dual education system in the railway industry]. Retrieved from https://www.railinsider.com.ua/v-uz-rozpovily-yak-vprovadzhuyetsya-dual [in Ukrainian].

3. Kovalenko, O. M. (2020). Pidhotovka maybutnikh fakhivtsiv zalianychnoho transport na pidpriiemstavakh Ukraiiny (80-ti - pochatok 90-kh rokiv XX st.) [Future railway experts training at the Ukrainian enterprises (80-s - the beginning of 90-s of the XX century)]. Kherson: KVNZ "Khersonska akademiia neperervnoii osvity" [in Ukrainian].

4. Kontseptsiia dualnoii osvity $\mathrm{v}$ Ukraiini [The concept of the dual education in Ukraine]. Retrieved from

https://www.google.com/url?sa=t\&rct=j\&q=\&esrc=s\&source=web\&cd=\&ved=2ahUKEwjHqcTsivH wAhXkhf0HHcwJC0EQFjABegQIBBAD\&url=https\%3A\%2F\%2Fmon.gov.ua\%2Fstorage\%2Fapp\% 2Fmedia\%2Fkolegiya-ministerstva\%2F02\%2Fkontseptsii-dualnoiosviti.doc\&usg=AOvVaw2NRBaEU9808aQDn9VXCli2 [in Ukrainian].

5. Slyusarenko, N. V., \& Kovalenko, A. N. (2018). Podgotovka spetsialistov zheleznodorozhnogo transporta: mezhdunarodnyy opyt [Railway experts training: international experience]. Astana [in Russian].

6. Trebovaniya $\mathrm{k}$ razrabotke uchebnykh planov $\mathrm{i}$ programm dlya podgotovki i povysheniia kvalifikatsii rabochykh na proizvodstve: ot 19 yanvarya 1983 goda [The requirement to the syllabi and curriculum for the training and upgrading qualification at the enterprises dated January 19, 1983]. Retrieved from http://docs.cntd.ru/document/420273676 [in Russian].

\section{ІМПЛЕМЕНТАЦІЯ ДОСВІДУ ПІДГОТОВКИ МАЙБУТНІХ ФАХІВЦІВ}

Коваленко О. М., orcid.org/0000-0001-7900-6226 ЗАЯІЗНИЧНОГО ТРАНСПОРТУ В СУЧАСНИЙ ОСВІТНІЙ ПРОЦЕС

Стаття присвячена впровадженню досвіду підготовки майбутніх фахівців залізничного транспорту в сучасний освітній процес. Зазначено, що проблема підготовки фахівців залізничного транспорту $е$ актуальною впродовж усього періоду існування залізничних навчальних закладів. Гострі питання, які поставали у процуесі підготовки фахівців залізничного транспорту, такі: наступність навчальних планів та навчальних програм на різних рівнях освіти, відповідність рівня підготовки умовам працุі та вимогам залізничного підприемства, система дуальної освіти тощз. У минулому (в другий половині ХХ століття) процес підготовки залізничних експертів був зумовлений кількома факторами. Одним із них став науково-технічний розвиток залізничного транспорту (наприклад, заліна парових потлгів 
та тепловозів на електровози; застосування автоматичних систем на залізниці тощо). Інший фактор - вимоги залізничного підприемства (з подальщим розвитком залізничного транспорту підприемства потребують більш квалібікованих робітників або фахівиів з новою кваліфікацією). Таким чином, залізнична галузь вимагала нових квалібікованих робітників, а заклад залізничної освіти мав спрялувати свою діяльність на підготовку квалібікованих робітників для різних залізничних галузей. Для досягнення цзієї мети професійно-технічні навчальні заклади започаткували нові спеціальності та створили нові навчальні плани інавчальні програми, які відповідали вимогам залізниці. Зроблено висновок, що, беручи до уваги попередній історичний досвід, було би доциіьно організувати підготовку майбутніх фахівців залізничного транспорту на відповідних підприемствах, залучаючи до неї фахівців, які працъюють на підприемстві. Акцентовано, щьо навчання на виробництві має займати більще половини загальної кількості годин освітньої програми. Такий підхід забезпечуе збалансоване засвоєння твердих та м'яких навичок: професійних знань та вмінь, необхідних ключових компетенцій, а також комунікативних навичок, командної роботи, критичного мислення тощо. Запропоновано авторський проєкт навчального плану, який може бути використаний для підготовки фахівців залізничного транспорту в рамках програми дуальної освіти.

Ключові слова: імплементація, дуальна освіта, навчальна програма, навчальний план, залізничники, підготовка фахівців залізничного транспорту.

Дата надходження статті: 15.01.2021 p. Рецензент: доктор педагогічних наук, доцент Яиула Т. В.

УДК 378.147

DOI https://doi.org/10.37915/pa.vi48.230

Куценко I. В. ,

orcid.org/0000-0001-5347-4101

\section{ПЕРЕДУМОВИ СТАНОВДЕННЯ ТА ПЕРІОДИЗАЦІЯ МОНІТОРИНГУ НАВЧАЯЬНИХ ДОСЯГНЕНЬ СТУ ДЕНТІВ МОРСЬКИХ НАВЧАЯЬНИХ ЗАКЛАДІВ УКРАЇНИ (ДРУГА ПОЯОВИНА ХХ - ПОЧАТОК ХХІ СТОЛІТТЯ)}

У статті висвітлено основні періоди становлення та розвитку моніторингу навчальних досягнень студентів морських навчальних закладів Украйни (друга половина ХX - початок ХХІ століття). Проаналізовано накази, звіти, протоколи засідань методичних об'єднань і педагогічних зібрань та інші документи, зміст яких пов'язаний із навчальною діяльністю морських навчальних закладів у цзілому та моніторингом. Аналіз історичної літератури показав, щуо становлення та розвиток моніторингу навчальних досягнень курсантів морських навчальних закладів поділяеться на чотири етапи. Охарактеризовано передумови становлення моніторингу навчальних досягнень курсантів. Уперше моніторинг навчальних досягнень студентів морських навчальних закладів почав практично організовуватися $і$ здійснюватися на початку 1940-х рр. у зв'язку з упровадженням педагогічних нововведень, які були закладені у 1930-роках. Становлення та розвиток моніторингу навчальних досягнень студентів морських навчальних закладів поділено на три періоди: 1944-1958 роки ХХ століття, що характеризується першими спробами організації моніторингу навчальних досягнень студентів морських навчальних закладів; 1959-1984 роки ХХ століття, що характеризується появою різних форм та методів моніторингу навчальних досягнень курсантів; 1985 - 2014 роки ХХ століттл, щзо характеризується розквітом та поширенням актуальності моніторингу навчальних досягнень у закладах морського профілю. Визначено причини суб'єктивізму бальної системи та проаналізовано історіографічні публікації,

*(C) Куценко I. В.

U3 245 